\title{
Jump Risk and Cross Section of Stock Returns: Evidence from China's Stock Market
}

Haigang Zhou

Cleveland State University, h.zhou16@csuohio.edu

John Qi Zhu

Follow this and additional works at: https://engagedscholarship.csuohio.edu/bus_facpub

Part of the Finance and Financial Management Commons

How does access to this work benefit you? Let us know!

Publisher's Statement

The final publication is available at Springer via http://dx.doi.org/10.1007/s12197-009-9097-z

\section{Original Published Citation}

Zhou, H., Zhu, J. (2011). Jump Risk and Cross Section of Stock Returns: Evidence from China's Stock Market. Journal of Economics and Finance, 35, pp. 309-331.

This Article is brought to you for free and open access by the Monte Ahuja College of Business at EngagedScholarship@CSU. It has been accepted for inclusion in Business Faculty Publications by an authorized administrator of EngagedScholarship@CSU. For more information, please contact library.es@csuohio.edu. 


\title{
Jump risk and cross section of stock returns: evidence from China's stock market
}

\author{
Haigang Zhou · John Qi Zhu
}

\begin{abstract}
Various studies have confirmed the existence of jumps in different financial markets. However, there is sparse theoretical or empirical effort to examine the dynamic relation between jump risk and cross-sectional expected stock returns. We follow a stylized SDF-based diffusion-jump model to examine its testable implications about the relation between cross-section expected excess returns and variations in jump intensities across stocks. The zero-cost portfolio, exploiting the return spreads between the top and bottom decile portfolios formed on jump intensity, could earn an annualized return as high as $24 \%$ with an annualized Sharpe ratio of 1.67 . A Fama-MacBeth test shows that stock excess returns monotonically decrease in jump intensity even after controlling for other common risk factors.
\end{abstract}

Keywords Instantaneous Volatility - Diffusion-jump - Fama-MacBeth Zero-cost · High-frequency · Tick-by-Tick - Stochastic Discount Factor

JEL Classification $\mathrm{G} 12 \cdot \mathrm{G} 15$

Haigang Zhou acknowledges financial support from Cleveland State University's Research Council Faculty Research Development (FRD) Program. We would like to thank the editor, James Payne, and an anonymous referee for helpful comments, as well as conference participants at the 2009 FMA Asian Conference.

H. Zhou

Department of Finance, Cleveland State University, Cleveland, $\mathrm{OH}$ 44115-2214, USA

e-mail: h.zhou16@csuohio.edu

J. Q. Zhu (凶)

Antai College of Economics \& Management, Shanghai Jiao Tong University, Shanghai 200052, China e-mail: qizhu@sjtu.edu.cn 


\section{Introduction}

The theoretical importance of incorporating sudden, infrequent, but often drastic price movements into asset pricing models has long been emphasized in the finance literature since Press (1967), Merton (1976), and Cox and Ross (1976). Previous studies have demonstrated the substantial impact of jumps in the field of portfolio and risk management, option and bond pricing, and hedging in various financial markets. ${ }^{1}$ There is, however, surprisingly sparse theoretical or empirical effort on understanding the dynamic relation of jump risk to cross-sectional expected stock returns. We follow a stylized SDF (Stochastic Discount Factor)-based diff usion-jump model to examine the testable implications for the cross sectional relation between expected excess returns and jump intensities. The latter is a proxy of firm's exposure to jump risk and defined as the monthly sum of absolute daily jump returns. Using high frequency trading data from China, we provide empirical evidence from an emerging market that is complementary to the existing literature on the topic predominantly resting on the U.S. market.

In this paper, we apply the continuous-time modeling framework of Yan (2008) to empirically test the systematicity of jump risk and to disentangle the risk premium borne from jumps. The model posits the stochastic discount factor and stock prices follow correlated diffusion-jump processes composed of a Brownian component and a Poisson component. The expected excess stock return compensates for two sources of systematic risks: a diffusive component due to the covariance between the Brownian motions of the SDF and of the stock price, and a jump component when the Poisson processes of the SDF and of the stock price are dependent. The expected excess stock return is solely determined by the conventional market $\beta$ if and only if jump risk is unsystematic (that is, the Poisson processes of the SDF and of the stock prices are uncorrelated), otherwise part of the cross-sectional variation in the expected excess returns can be predicted by jump characteristics of stocks. One implication of the model is that, if the average jump size of SDF is positive, the expected excess return is monotonically decreasing in the jump intensity of the stock, ceteris paribus. We further test the profitability of a simple trading strategy based on this cross-sectional pattern.

The accurate detection of jumps and concrete estimation of their sizes are crucial to measure the jump intensity, a key element in our empirical analysis. A flurry of studies have proposed various methods to detect jump arrivals and to measure realized jump sizes. ${ }^{2}$ Among them, we adopt a non-parametric approach suggested by Lee and Mykland $(2008)$. Their detection technique can

\footnotetext{
${ }^{1}$ See, for example, Ball and Torous (1985), Bakshi et al. (1997), Bates (2000), Duffie et al. (2000), Andersen et al. (2002), Pan (2001), Eraker et al. (20013), Naik and Lee (1990), Johnnes (2004).

${ }^{2}$ See for instance, Aït-Sahalia (20)4), Andersen et al. (20)(2), Barndorff-Nielsen and Shephard (2016), Bollerslev et al. (2001) , Eraker (2004), Eraker et al. (20013), Jiang and Oomen (2008), Maheu and McCurdy (2004), Yan (2008) and Zhou and Zhu (200\%).
} 
precisely identify the intervals over which jumps occur and allow for multiple occurrence of jumps in a trading day. Moreover, for the purpose of obtaining a joint measure of jump frequency and jump size, the Lee and Mykland method is more straightforward and intuitive compared to approaches developed in other studies.

We employ the Lee and Mykland jump detection technique to high frequency trading data for each A Share stock traded on the Shanghai Stock Exchange from January 2003 to September 2008. For each stock, we identify the intra-day intervals over which jumps arrive, calculate jump returns over the intervals, and define monthly accumulative absolute jump returns a proxy for the jump intensity that embodies the information of both average jump size and jump frequency of the stock. We then form decile (or quintile) portfolios sorted on the jump intensity and hold them for one month. The Fama-MacBeth test presents strong evidence in favor of the existence of systematic jump risk in stock portfolios and confirms our conjuncture that expected excess stock returns are monotonically decreasing in jump intensity. A zero-cost portfolio exploiting the return spreads between the top and bottom decile portfolios could earn an annualized return as high as $24 \%$ with an annualized Sharpe ratio of 1.67. The results are robust to a set of firm characteristic variables, including market risk, past and idiosyncratic returns, size, book-to-market ratio, lagged volatility, turnover ratio, and illiquidity.

The rest of the paper proceeds as follows. In Section 2, we present the theoretical model, derive the testable implications, and briefly describe the method of detecting jumps and estimating jump sizes. Section 3 details the construction of variables and testing portfolios. We present empirical results in Section 4 and conclude in Section 5 .

\section{Methodology}

\subsection{Jumps and asset pricing}

We follow the continuous-time modeling approach of Yan (20)(s) to formulate diffusion-jump processes for the stochastic discount factor and the stock price. We define $M(t)$ as a stochastic discount factor (SDF) with a positive stochastic process such that $M S_{i}$ is a martingale for the $i$ th stock price process $S_{i}(t)$. For example, $M$ is the intertemporal marginal rate of substitution for a representative investor in the consumption-based CAPM of Breeden (1979). The following identity,

$$
E_{t}\left[d\left(M S_{i}\right)\right]=0,
$$

thus states that the marginal utility-weighted prices follow a martingale, where $E_{t}[$.$] is the expectation conditional on information available at the time t$. Most existing asset pricing models can be unified under the stochastic discount factor framework (See Cochrane 2005, for example). 
$M(t)$ and $S_{i}(t)$ follow the below diffusion-jump processes:

$$
\begin{aligned}
& \frac{d M}{M}=\left(-r_{f}-\lambda_{M} \mu_{J_{M}}\right) d t+\sigma_{M} d W_{M}+J_{M} d N_{M}, \\
& \frac{d S_{i}}{S_{i}}=\left(\mu_{i}-\lambda_{i} \mu_{J_{i}}\right) d t+\sigma_{i} d W_{i}+J_{i} d N_{i},
\end{aligned}
$$

where $W_{M(i)}$ is a standard Brownian motion and $N_{M(i)}$ is a Poisson process with intensity $\lambda_{M(i)} \geq 0$, i.e., $\operatorname{Prob}\left(d N_{M(i)}=1\right)=\lambda_{M(i)} d t . r_{f}$ is the risk-free rate and $\mu_{i}$ is the average return for stock $i$. The term $\lambda_{M(i)} \mu_{J_{M(i)}}$ in Eq. 2 is the adjustment in the drift due to the average jump size. $\sigma_{M(i)}$ is the instantaneous diffusive standard deviation. $W_{M(i)}, N_{M(i)}$, and $J_{M(i)}$ are independent of each other by assumption, but they are pairwise correlated with $\operatorname{Corr}\left(d W_{M}, d W_{i}\right)=\rho_{i}$, $\operatorname{Corr}\left(d N_{M}, d N_{i}\right)=\eta_{i}$, and $\operatorname{Corr}\left(\ln \left(1+J_{M}\right), \ln \left(1+J_{i}\right)\right)=\psi_{i}$, respectively. $\eta_{i}$ is non-negative. ${ }^{3}$ The jump size is determined by $J_{M(i)}$, which is lognormally distributed over time:

$$
\ln \left(1+J_{M(i)}\right) \sim N\left(\ln \left(1+\mu_{J_{M(i)}}\right)-\frac{1}{2} \sigma_{J_{M(i)}}^{2}, \sigma_{J_{M(i)}}^{2}\right) .
$$

After decomposing the Brownian motions and Poisson processes into common factors and idiosyncratic components (See Yan 2008, for details), we apply the Itô's formula to $M S_{i}$ in an alternative representation of the SDF and stock price processes and get:

$$
\begin{aligned}
\frac{d\left(M S_{i}\right)}{M S_{i}}= & \left(\mu_{i}-r_{f}+\mu_{i} \sigma_{M} \sigma_{i}-\lambda_{M} \mu_{J_{M}}-\lambda_{i} \mu_{J_{i}}\right) d t+\sigma_{M} d W_{M}+\sigma_{i} d W_{i} \\
& +J_{M} d N_{M}+J_{i} d N_{i}+J_{M} J_{i} d N_{C}
\end{aligned}
$$

where $N_{C}$ is the common factor that drives both $N_{M}$ and $N_{i}$ in the decomposition of Poisson processes. Using Eq. 1, log-normality of $J_{M(i)}$, and some ad hoc approximations, we obtain the asset pricing equation that underlies our subsequent empirical analysis:

$$
\mu_{i}-r_{f} \approx-\rho_{i} \sigma_{M} \sigma_{i}-\eta_{i} \sqrt{\lambda_{M} \lambda_{i}}\left[\psi_{i} \sigma_{J_{M}} \sigma_{J_{i}}\left(1+\mu_{J_{M}}\right)\left(1+\mu_{J_{i}}\right)+\mu_{J_{M}} \mu_{J_{i}}\right] .
$$

The LHS is the usual excess return on stock $i$. The first term on the RHS is the continuous time analogue of the discrete-time $\beta$-representation of expected returns. If the diff usive process of stock returns, $d W_{i}$, negatively

\footnotetext{
${ }^{3}$ The intuition behind the non-negativity restriction on the parameter $\eta$ is that a market wide jump in SDF might have negligible effects on the likelihood of jump occurrences in individual assets, and most likely there is some positive correlation between the two. However, it is hard to imagine some market wide jumps would indeed depress or dampen the likelihood of jump arrivals to assets with negative correlation. It is also instrumental for the purpose of model identification that becomes more explicit later.
} 
covaries with that of SDF, $d W_{M}$, the expected stock return must be higher than the risk free rate $\left(\rho_{i}<0\right)$; in the discrete-time framework, positive expected excess returns come from positive $\beta$ which in turn is a reflection of negative covariation between the SDF and the stock return. In Eq. 6, the expected excess stock returns not only depend on the risk premium from the continuous sample path, but critically hinge on the premium (or discount) driven by the discontinuous/jump component in the asset price. In particular, if jumps are present but are not systematic $\left(\eta_{i}=0\right)$ as Merton (1976) has argued, the second term in Eq. 6 completely drops out, and consequently, expected stock returns would not compensate for idiosyncratic jump risks.

When the systematic jump risk is present $\left(\eta_{i}>0\right)$, two components in the brackets on the RHS, in addition to the market $\beta$, jointly determine the magnitude of excess stock returns. The sign of the first component relies on $\psi_{i}$, the correlation coefficient of jump sizes of $M$ and $S_{i}$. If the jump size of stock is negatively correlated with the jump size of SDF, the expected excess return will be higher, ceteris paribus. In the special case when $\psi_{i}=0$, the impact of the second component on the expected excess return stands out in a simplified version of Eq. 6:

$$
\mu_{i}-r_{f} \approx-\rho_{i} \sigma_{M} \sigma_{i}-\eta_{i} \sqrt{\lambda_{M} \lambda_{i}} \mu_{J_{M}} \mu_{J_{i}}
$$

Equation 7 implies that, if the jump size of stock is uncorrelated with the jump size of $M$ (i.e., $\psi_{i}=0$ ), but the sign of average stock jump size is opposite to the sign of average SDF jump size (i.e., $\mu_{J_{M}} \mu_{J_{i}}<0$ ), the stock earns higher returns, ceteris paribus; on the contrary, if the average jump size of stock has the same sign as the average jump size of $M$, the expected excess return will be dampened or lower, ceteris paribus. To spell out a testable hypothesis from Eq. 7 on the predictability of cross-sectional expected excess returns associated with cross-sectional variations in jump risks, it is essential to determine the sign of the parameter $\mu_{J_{M}}$. According to existing asset pricing models (see Bakshi et al. 1997; Bates 2000); Pan 2002); Eraker et al. 20013; Rietz 1988; Barro 2006; Yan $200 \%$, for details), the sign of average SDF jump size is positive, $\mu_{J_{M}}>0$. We can therefore formulate the following hypothesis:

Hypothesis 1 If the average SDF jump size is positive, excess stock returns are monotonically decreasing in the jump intensity that is the product of average jump size $\left(\mu_{s_{i}}\right)$ and jump frequency $\left(\lambda_{i}\right)$ across stocks or portfolios, when there is zero correlation between jump sizes of the stocks and the $S D F$.

Following Eq. 7, we propose the following Fama-McBeth regression to test the above hypothesis:

$$
\mathrm{E}\left(r_{i}\right)-r_{f}=\alpha+\gamma_{1} r_{i}^{j t m p}+\gamma_{2} \beta_{i}+\gamma_{3} X_{i}+\varepsilon_{i},
$$

where $r_{i}^{j u m p}$ is a proxy for jump intensity, summarizing $\sqrt{\lambda_{i}} \mu_{J_{i}}$ in Eq. 7 , and $X_{i}$ is a set of control variables, e.g., market capitalization, turnover, illiquidity, etc. (See Section 3.2 for more details). We detail the empirical strategy to identify 
and estimate firm-specific jump parameters, $\lambda_{i}$ and $\mu_{J_{i}}$, in Section 2.2. Note that $\eta_{i}$ jointly determines the stock excess returns in Eq. 7, but remains unobserved for each individual stock in our empirical analysis. Equation 8 is therefore inappropriate to apply directly to the cross section of individual stocks and becomes a misspecified test for Eq. 7. However, assuming $\eta_{i}, \mu_{J_{i}}$, and $\lambda_{i}$ are independent across stocks, we can easily separate the portfolio average of $\eta_{i}$ from the portfolio average of the product $\mu_{J_{i}}$ and $\lambda_{i}$ for each well-diversified portfolio sorted on jump intensity. If portfolio size is large enough, portfolio averages of $\eta_{i}$ converge to the population mean of $\eta_{i}$. Thus when testing assets are portfolios instead of individual stocks, $\eta_{i}$ becomes a constant across portfolios, which validates the specification in Eq. $\$$.

\subsection{Identification and measurement of jumps}

Suppose a jump arrives in the market and affects the stock price at time $t_{\tau}$, the realized asset return at time $t_{\tau}$ must be much higher than usual continuous innovations. However, higher-than-usual returns are not only caused by jumps but also by high volatilities exclusively attributed to the continuous sample path in the price process. In order to statistically distinguish between higherthan-usual realized returns caused by jumps and those associated with high volatilities not related to jumps, we follow Lee and Mykland (200) to detect jumps using the ratio of a realized return to the instantaneous volatility, $\sigma\left(t_{\tau}\right)$, which is estimated from the local movement in the continuous part of the price process.

Lee and Mykland (20)8) proposes the following statistic to detect the occurrence of jumps from $t_{\tau-1}$ to $t_{\tau}$ :

$$
\mathcal{L}(\tau) \equiv \frac{\ln S\left(t_{\tau}\right)-\ln S\left(t_{\tau-1}\right)}{\widehat{\sigma\left(t_{\tau}\right)}},
$$

where $S(t)$ is the asset price at time $t$ that follows the diffusion-jump process described in Eq. 3. $\widehat{\sigma\left(t_{\tau}\right)}$ is a consistent estimator of instantaneous volatility even when jumps are present in previous time periods,

$$
\widehat{\sigma\left(t_{\tau}\right)}=\sqrt{\frac{1}{K-2} \sum_{j=\tau-K+2}^{\tau-1}\left|\ln S\left(t_{j}\right)-\ln S\left(t_{j-1}\right)\right|\left|\ln S\left(t_{j-1}\right)-\ln S\left(t_{j-2}\right)\right|},
$$

where $K$ is the window size within which the corresponding local movements of the price process are considered. The impact of jumps on the estimated volatility diminishes as the window size $K$ increases.

Lee and Mykland $(2008)$ shows that the maximums of the $\mathcal{L}(\tau)$ under the absence of jumps during any arbitrarily small interval $\left(t_{\tau-1}, t_{\tau}\right]$ has the following limiting distribution:

$$
\frac{\max _{\tau \in \bar{A}_{n}}|\mathcal{L}(\tau)|-C_{n}}{S_{n}} \rightarrow \xi,
$$


where $\xi$ has $\operatorname{CDF} P(\xi \leq x)=\exp \left(-e^{-x}\right), \bar{A}_{n}$ is the set of $\tau \in\{1,2, \ldots n\}$ such that there is no jump in $\left(t_{\tau-1}, t_{\tau}\right]$, and $n$ is the number of total observations,

$$
C_{n}=\frac{\sqrt{2 \ln n}}{c}-\frac{\ln \pi+\ln (\ln n)}{2 c \sqrt{2 \ln n}}, \quad \text { and } \quad S_{n}=\frac{1}{c \sqrt{2 \ln n}} \text {, }
$$

where $c=\sqrt{2} / \sqrt{\pi} \approx 0.7979$. To choose the threshold value $\beta^{*}$ for the rejection region at the significance level of $1 \%$, we solve cumulative distribution function $P\left(\xi \leq \beta^{*}\right)=\exp \left(-e^{-\beta^{*}}\right)=0.99$ for $\beta^{*}$ and obtain $\beta^{*}=4.6001$. Therefore, if $\frac{|\mathcal{L}(\tau)|-C_{I}}{S_{n}}>4.6001$, we reject the hypothesis that no jump arrives in the interval $\left(t_{\tau-1}, t_{\tau}\right]$.

In the following empirical analysis, we implement the Lee and Mykland method on 15-min high frequency data of individual A-share stocks in the Shanghai Stock Exchange. Following the recommendation of Lee and Mykland (20)(S), we set the window size, $K$, at 156 in estimating instantaneous volatilities.

If a jump is detected at $t_{\tau}$, we denote that 15 -min log return as the jump return. The method allows for multiple jumps on a given trading day. We then calculate the daily jump return as the the summation of 15-min jump returns, if there are any, during the day. We denote the daily jump return for stock $i$ on trading day $d$ as $r_{i, d}^{j u m p}$. On trading days with no detected jumps, the jump return is set to be zero. For each month we calculate the sum of absolute daily jump returns and call it jump intensity, $r_{i, t}^{j u m p}=\sum_{d=1}^{N_{t}}\left|r_{i, d}^{j t u m p}\right|$, where $N_{t}$ is the total number of trading days in month $t^{4}$ We use jump intensity, $r_{i}^{\text {jump }}$, as our ultimate measure of cross-sectional variations in the interaction between jump frequency and average jump size, a proxy for $\left(\sqrt{\lambda_{i}} \mu_{J_{i}}\right)$ in Eq. 7. As a robustness check, we experiment in the empirical analysis a couple of alternative measures that proxy for the product of average jump size and jump intensity. None of the alternative measures changes our main results.

\section{Data, variable construction, and portfolio forming strategy}

We collect high-frequency stock transaction data from The Analyst Database from January 2003 to September 2008 for all A Share stocks traded on the Shanghai Stock Exchange. To avoid the market microstructure noise that might affect the result, we transform the raw data to 15 -min returns for our empirical analysis. Lee and Mykland (2008) shows that the test is robust to microstructure noises at 15 -min intervals.

${ }^{4}$ With a little abuse of notation, we designate subscript $t$ hereafter to observations at monthly frequency only. 
Unlike the NYSE, the trading hours of the Shanghai Stock Exchange span two sessions on a trading day: a morning session from 9:30AM to 11:30AM and an afternoon session from 1:00PM to 3:00PM, with a lunch break in between. Therefore, the first 15-min log return of a trading day is calculated from trading prices between 9:30:01AM and 9:45:00AM, and the last 15-min return in the morning session is between 11:15:01AM and 11:30:00AM. The first return observed in the afternoon session is from 1:30:01PM to 1:45:00PM and the last from 2:45:01PM to 3:00:00PM. At most we have 16 observations of 15 -min returns in a trading day provided there is at least one transaction in every 15 -min interval. We treat returns over non-trading intervals as missing values and exclude them from our analysis.

We further restrict our sample to those trading days with at least 10 observations of 15-min returns to minimize the impact of infrequent trading on our empirical results. To eliminate the irregular and extreme price movements in days immediately following initial public offerings, we exclude the first 22 trading days for each stock first appearing in the data set. Finally, we apply the "Sandwich Filter" to eliminate trading days with absolute returns larger than 10 percent because it contradicts to the existing institutional 10 -percent limit on daily stock price movement in the Shanghai Stock Exchange.

\subsection{Portfolio forming strategy}

At the beginning of month $t$, we sort stocks in an ascending order by their jump intensities in month $t-1$ and group them into equally weighted quintile or decile portfolios. We buy the portfolios at the beginning of month $t$ and sell them at the end of month $t$. We repeat the process every month to obtain a time series of equally weighted portfolio returns. We also form a zero-jump portfolio that includes stocks with no detected jumps in the previous month. Thus, in total we have six or eleven equally weighted testing portfolios sorted on jump intensities.

To control for other explanatory variables that may predict cross-sectional returns, we follow the two-pass sort approach of Fama and French (199.3) to build $5 \times 6$ portfolios: We first allocate stocks into five quintile portfolios using other explanatory variables and then divide stocks within each quintile into six portfolios based on jump intensity. ${ }^{5}$

\subsection{Variable construction}

We obtain monthly market capitalization (ME) and market to book ratio (MB) from CSMAR database, where book value of equity is the sum of shareholder' equity without minority and minority shareholders' equity. Both are collected

\footnotetext{
${ }^{5}$ For each month, there are a maximum of 850 stocks to allocate into $30(5 \times 6)$ portfolios. On average, each portfolio has about 30 stocks. We don't conduct decile portfolio analysis because the small number of stocks in each portfolio is not sufficient to conduct any meaningful test.
} 
at the end of each month. Following Amihud (20)(2), Illiquidity (ILLIQ) is measured by the monthly average ratio of absolute daily stock returns to daily trading value. Stock turnover ratio (TO) is the total trading value in a month divided by the market capitalization. Market $\beta$ is estimated from rolling regressions of stock returns on returns of the Shanghai Stock Exchange A Share Index over the previous 48 months. Past return $r_{t-1}$ is the stock return in the month when portfolios are formed. Past idiosyncratic return is defined as $r^{\text {idio }}=r-\beta R_{M}$, where $R_{M}$ is the return of Shanghai Stock Exchange A Share Index in the holding month. $\sigma_{r_{t-1}}$ is lagged monthly volatility of daily stock returns.

We obtain data on Fama/French three factors in Chinese market from RESSET/DB database. SMB (Small Minus Big) is the average return on the three small portfolios minus the average return on the three big portfolios: $\mathrm{SMB}=1 / 3($ Small Value + Small Neutral + Small Growth $)-1 / 3($ Big Value + Big Neutral + Big Growth). HML (High Minus Low) is the average return on the two value portfolios minus the average return on the two growth portfolios: $\mathrm{HML}=1 / 2$ (Small Value + Big Value) $-1 / 2$ (Small Growth + Big Growth). $R_{M}-R_{f}$, the excess return on the market, is the difference between the valueweighted return on all Chinese stocks (from CSMAR) and the three-month bank deposit rate (from China's central bank, the People's Bank of China).

\section{Empirical results}

\subsection{Summary statistics of jumps}

Table 1 reports the summary statistics of jump-related variables for all A Share stocks traded on the Shanghai Stock Exchange (SSE) between January 2003 and September 2008. Stock jumps are identified using the Lee and Mykland (20)(8) method at $1 \%$ significance level.

The table confirms that jumps are rare events. There is a $6.80 \%$ chance for an average stock to have a price jump on any given trading day. The table shows that there is considerable cross-sectional variation in jump frequencies. Jumps occur at minimum $3.30 \%$ and at maximum $23.10 \%$ of all trading days cross individual stocks in the Shanghai Stock Exchange. The cross-sectional mean of firm-level jump frequencies for A Share stocks in the SSE is much lower than $12.07 \%$, the cross section average of firm-level jump frequencies for S\&P 100 stocks reported in Dunham and Friesen (20)(7). Zhou and Zhu (2009b) (Table 2 Panel A) report a 7.79\% average jump frequency across the 50 largest A share stocks listed in the Shanghai Stock Exchange. For a typical stock, positive price jumps, defined as jumps causing positive intraday interval returns, occur more often than negative jumps, $4.30 \%$ vs. $2.50 \%$ of all trading days. On average, the positive jump gives the stock a $5.00 \%$ daily price increase while the negative jump results in a $5.20 \%$ drop in prices. These results indicate an asymmetric effects that firm-level jumps exert on the stock returns. Although negative jumps occur less frequently, they typically result in 
Table 1 Summary statistics of jumps

\begin{tabular}{|c|c|c|c|c|c|c|c|c|c|}
\hline & Min. & $5 \%$ & $25 \%$ & Mean & Median & $75 \%$ & $95 \%$ & Max. & Std. \\
\hline No. of trading days & 39 & 436 & 1162 & 1169.733 & 1277 & 1306 & 1318 & 1343 & 255.217 \\
\hline Ratio (jump-days, trading days) (\%) & $3.30 \%$ & $4.60 \%$ & $5.50 \%$ & $6.80 \%$ & $6.40 \%$ & $7.60 \%$ & $10.80 \%$ & $23.10 \%$ & $2.00 \%$ \\
\hline Ratio (pos. jump-days, trading days) (\%) & $0.00 \%$ & $2.70 \%$ & $3.50 \%$ & $4.30 \%$ & $4.10 \%$ & $4.80 \%$ & $6.50 \%$ & $9.40 \%$ & $1.20 \%$ \\
\hline Ratio (neg. jump-days, trading days) (\%) & $0.80 \%$ & $1.50 \%$ & $1.90 \%$ & $2.50 \%$ & $2.20 \%$ & $2.80 \%$ & $4.60 \%$ & $15.40 \%$ & $1.10 \%$ \\
\hline Average number of jumps & 0.035 & 0.049 & 0.06 & 0.073 & 0.069 & 0.082 & 0.116 & 0.256 & 0.021 \\
\hline Average number of jumps on jump days & 1 & 1.025 & 1.052 & 1.079 & 1.075 & 1.1 & 1.148 & 1.385 & 0.039 \\
\hline $\begin{array}{l}\text { Average jump return } \\
\text { on jump days (\%) }\end{array}$ & -0.037 & -0.001 & 0.007 & 0.012 & 0.013 & 0.018 & 0.026 & 0.047 & 0.008 \\
\hline $\begin{array}{l}\text { Average jump return on positive } \\
\text { jump days }(\%)\end{array}$ & $3.20 \%$ & $4.00 \%$ & $4.50 \%$ & $5.00 \%$ & $5.00 \%$ & $5.40 \%$ & $6.10 \%$ & $8.60 \%$ & $0.70 \%$ \\
\hline $\begin{array}{l}\text { Average jump return on negative } \\
\text { jump days }(\%)\end{array}$ & $-7.00 \%$ & $-6.20 \%$ & $-5.70 \%$ & $-5.20 \%$ & $-5.20 \%$ & $-4.80 \%$ & $-4.00 \%$ & $-2.60 \%$ & $0.70 \%$ \\
\hline $\begin{array}{l}\text { Average absolute jump return on } \\
\text { jump days }(\%)\end{array}$ & $3.30 \%$ & $4.10 \%$ & $4.60 \%$ & $5.10 \%$ & $5.10 \%$ & $5.50 \%$ & $6.00 \%$ & $7.50 \%$ & $0.60 \%$ \\
\hline
\end{tabular}

This table reports the cross-sectional summary statistics of jump variables. Number of Trading Days are the total number of trading days over the sample period. Ratio(Jump-days, Trading days) is calculated for each firm as the ratio of the number of jump days to the total number of trading days, where jump days are those days identified as having jumps using the Lee and Mykland (200s) method. Ratio(Pos. jump-days, Trading days) (or Ratio(Neg. jump-days, Trading days)) is the ratio of the number of days identified as having positive (or negative) jumps to the total number of trading days. Average Number of Jumps is the ratio of total number of jumps to the total number of trading days. Average Number of Jumps on Jump Days is the ratio of total number of jumps to the total number of jump days. Average (Absolute) Jump Return on Jump Days is the sum of (the absolute values of) daily jump returns divided by the total number of jump days, where the daily jump retum is defined as the daily sum of 15 -min returns over intervals that jump is identified using the Lee and Mykland (200) method. Average Jump Return on Positive (Negative) Jump Days is the sum of daily jump returns divided by the total number of days with positive (negative) daily jump returns 
Table 2 Summary statistics on the distribution of jump intervals and jump days

\begin{tabular}{|c|c|c|c|c|c|c|c|c|c|c|c|c|c|c|}
\hline & \multicolumn{2}{|l|}{2003} & \multicolumn{2}{|l|}{2004} & \multicolumn{2}{|l|}{2005} & \multicolumn{2}{|l|}{2006} & \multicolumn{2}{|l|}{2007} & \multicolumn{2}{|l|}{2008} & \multicolumn{2}{|l|}{ Total } \\
\hline & Count & Percent & Count & Percent & Count & Percent & $\overline{\text { Count }}$ & Percent & Count & Percent & $\overline{\text { Count }}$ & Percent & Count & $\overline{\text { Percent }}$ \\
\hline \multicolumn{15}{|c|}{ Panel A: frequency of jump intervals } \\
\hline \multicolumn{15}{|l|}{ Time interval } \\
\hline$(9: 30 \mathrm{AM}, 9: 45 \mathrm{AM}]$ & 2871 & $32.1 \%$ & 4426 & $42.0 \%$ & 4883 & $42.3 \%$ & 6058 & $47.1 \%$ & 9994 & $56.1 \%$ & 8117 & $67.9 \%$ & 36349 & $49.4 \%$ \\
\hline (9:45 AM, 10:00 AM] & 757 & $8.5 \%$ & 1031 & $9.8 \%$ & 890 & $7.7 \%$ & 893 & $6.9 \%$ & 1103 & $6.2 \%$ & 926 & $7.7 \%$ & 5600 & $7.6 \%$ \\
\hline (10:00 AM, 10:15 AM] & 694 & $7.8 \%$ & 571 & $5.4 \%$ & 461 & $4.0 \%$ & 603 & $4.7 \%$ & 537 & $3.0 \%$ & 178 & $1.5 \%$ & 3044 & $4.1 \%$ \\
\hline (10:15 AM, 10:30 AM] & 505 & $5.6 \%$ & 394 & $3.7 \%$ & 378 & $3.3 \%$ & 440 & $3.4 \%$ & 528 & $3.0 \%$ & 158 & $1.3 \%$ & 2403 & $3.3 \%$ \\
\hline (10:30 AM, 10:45 AM] & 823 & $9.2 \%$ & 1178 & $11.2 \%$ & 959 & $8.3 \%$ & 884 & $6.9 \%$ & 1265 & $7.1 \%$ & 923 & $7.7 \%$ & 6032 & $8.2 \%$ \\
\hline (10:45 AM, 11:00 AM] & 300 & $3.4 \%$ & 345 & $3.3 \%$ & 341 & $3.0 \%$ & 357 & $2.8 \%$ & 323 & $1.8 \%$ & 153 & $1.3 \%$ & 1819 & $2.5 \%$ \\
\hline (11:00 AM, 11:15 AM] & 233 & $2.6 \%$ & 266 & $2.5 \%$ & 273 & $2.4 \%$ & 333 & $2.6 \%$ & 277 & $1.6 \%$ & 137 & $1.1 \%$ & 1519 & $2.1 \%$ \\
\hline (11:15 AM, 11:30 AM] & 392 & $4.4 \%$ & 347 & $3.3 \%$ & 320 & $2.8 \%$ & 521 & $4.1 \%$ & 567 & $3.2 \%$ & 139 & $1.2 \%$ & 2286 & $3.1 \%$ \\
\hline (1:00 PM, 1:15 PM] & 219 & $2.4 \%$ & 252 & $2.4 \%$ & 258 & $2.2 \%$ & 346 & $2.7 \%$ & 318 & $1.8 \%$ & 150 & $1.3 \%$ & 1543 & $2.1 \%$ \\
\hline (1:15 PM, 1:30 PM] & 213 & $2.4 \%$ & 205 & $1.9 \%$ & 308 & $2.7 \%$ & 327 & $2.5 \%$ & 260 & $1.5 \%$ & 84 & $0.7 \%$ & 1397 & $1.9 \%$ \\
\hline (1:30 PM, 1:45 PM] & 301 & $3.4 \%$ & 221 & $2.1 \%$ & 263 & $2.3 \%$ & 306 & $2.4 \%$ & 253 & $1.4 \%$ & 159 & $1.3 \%$ & 1503 & $2.0 \%$ \\
\hline (1:45 PM, 2:00 PM) & 184 & $2.1 \%$ & 183 & $1.7 \%$ & 257 & $2.2 \%$ & 331 & $2.6 \%$ & 239 & $1.3 \%$ & 137 & $1.1 \%$ & 1331 & $1.8 \%$ \\
\hline (2:00 PM, 2:15 PM] & 226 & $2.5 \%$ & 209 & $2.0 \%$ & 312 & $2.7 \%$ & 302 & $2.3 \%$ & 379 & $2.1 \%$ & 89 & $0.7 \%$ & 1517 & $2.1 \%$ \\
\hline (2:15 PM, 2:30 PM] & 404 & $4.5 \%$ & 187 & $1.8 \%$ & 566 & $4.9 \%$ & 357 & $2.8 \%$ & 539 & $3.0 \%$ & 140 & $1.2 \%$ & 2193 & $3.0 \%$ \\
\hline (2:30 PM, 2:45 PM] & 251 & $2.8 \%$ & 208 & $2.0 \%$ & 410 & $3.6 \%$ & 368 & $2.9 \%$ & 476 & $2.7 \%$ & 196 & $1.6 \%$ & 1909 & $2.6 \%$ \\
\hline$(2: 45 \mathrm{PM}, 3: 00 \mathrm{PM}]$ & 578 & $6.5 \%$ & 523 & $5.0 \%$ & 652 & $5.7 \%$ & 429 & $3.3 \%$ & 747 & $4.2 \%$ & 275 & $2.3 \%$ & 3204 & $4.4 \%$ \\
\hline Total & 8951 & $12 \%$ & 10546 & $14 \%$ & 11531 & $16 \%$ & 12855 & $17 \%$ & 17805 & $24 \%$ & 11961 & $16 \%$ & 73649 & $100 \%$ \\
\hline
\end{tabular}


Table 2 (continued)

\begin{tabular}{|c|c|c|c|c|c|c|c|c|c|c|c|c|c|c|}
\hline & \multicolumn{2}{|l|}{2003} & \multicolumn{2}{|l|}{2004} & \multicolumn{2}{|l|}{2005} & \multicolumn{2}{|l|}{2006} & \multicolumn{2}{|l|}{2007} & \multicolumn{2}{|l|}{2008} & \multicolumn{2}{|l|}{ Total } \\
\hline & Count & Percent & Count & Percent & Count & Percent & Count & Percent & Count & Percent & $\overline{\text { Count }}$ & Percent & Count & Percent \\
\hline \multicolumn{15}{|c|}{ Panel B: frequency of jump intervals by months } \\
\hline \multicolumn{15}{|c|}{ Month } \\
\hline Jan. & & & 769 & $7.3 \%$ & 1066 & $9.2 \%$ & 994 & $7.7 \%$ & 1681 & $9.4 \%$ & 2047 & $17.1 \%$ & 6557 & $8.9 \%$ \\
\hline Feb. & 26 & $0.3 \%$ & 884 & $8.4 \%$ & 519 & $4.5 \%$ & 617 & $4.8 \%$ & 1332 & $7.5 \%$ & 516 & $4.3 \%$ & 3894 & $5.3 \%$ \\
\hline Mar. & 710 & $7.9 \%$ & 644 & $6.1 \%$ & 1206 & $10.5 \%$ & 881 & $6.9 \%$ & 1467 & $8.2 \%$ & 1006 & $8.4 \%$ & 5914 & $8.0 \%$ \\
\hline Apr. & 1378 & $15.4 \%$ & 1248 & $11.8 \%$ & 1524 & $13.2 \%$ & 1575 & $12.3 \%$ & 2155 & $12.1 \%$ & 1317 & $11.0 \%$ & 9197 & $12.5 \%$ \\
\hline May & 571 & $6.4 \%$ & 499 & $4.7 \%$ & 700 & $6.1 \%$ & 1424 & $11.1 \%$ & 2259 & $12.7 \%$ & 785 & $6.6 \%$ & 6238 & $8.5 \%$ \\
\hline Jun. & 674 & $7.5 \%$ & 992 & $9.4 \%$ & 950 & $8.2 \%$ & 970 & $7.5 \%$ & 2740 & $15.4 \%$ & 2068 & $17.3 \%$ & 8394 & $11.4 \%$ \\
\hline Jul. & 768 & $8.6 \%$ & 778 & $7.4 \%$ & 1298 & $11.3 \%$ & 1101 & $8.6 \%$ & 880 & $4.9 \%$ & 534 & $4.5 \%$ & 5359 & $7.3 \%$ \\
\hline Aug. & 720 & $8.0 \%$ & 1147 & $10.9 \%$ & 1264 & $11.0 \%$ & 990 & $7.7 \%$ & 1307 & $7.3 \%$ & 1238 & $10.4 \%$ & 6666 & $9.1 \%$ \\
\hline Sep. & 884 & $9.9 \%$ & 1133 & $10.7 \%$ & 969 & $8.4 \%$ & 985 & $7.7 \%$ & 1287 & $7.2 \%$ & 2450 & $20.5 \%$ & 7708 & $10.5 \%$ \\
\hline Oct. & 990 & $11.1 \%$ & 900 & $8.5 \%$ & 780 & $6.8 \%$ & 954 & $7.4 \%$ & 1250 & $7.0 \%$ & & & 4874 & $6.6 \%$ \\
\hline Nov. & 1069 & $11.9 \%$ & 630 & $6.0 \%$ & 580 & $5.0 \%$ & 1014 & $7.9 \%$ & 605 & $3.4 \%$ & & & 3898 & $5.3 \%$ \\
\hline Dec. & 1161 & $13.0 \%$ & 922 & $8.7 \%$ & 675 & $5.9 \%$ & 1350 & $10.5 \%$ & 842 & $4.7 \%$ & & & 4950 & $6.7 \%$ \\
\hline Total & 8951 & $12 \%$ & 10546 & $14 \%$ & 11531 & $16 \%$ & 12855 & $17 \%$ & 17805 & $24 \%$ & 11961 & $16 \%$ & 73649 & $100 \%$ \\
\hline
\end{tabular}

Panel $\mathrm{A}$ of the table reports the distribution of jumps among different 15-min intervals and Panel $\mathrm{B}$ reports the distribution of jumps among different months, both in different sample years and over the overall sample period. Count is the total number of jumps identified during a sample year (or over the entire sample period), and Percent is the percentage of jumps occurred over different 15 -min intervals, grouped either by year or over the entire the sample period. The last row of each panel reports the tolal numbers and percentages of jumps occurred in different sample years 
slightly larger price impacts. The majority of stocks have at most one jump per trading day, and on average, there are 1.08 jumps on a jump day.

Table 2 reports the summary statistics on the distribution of intraday jump intervals in Panel A and that of jump months in Panel B. The results indicate that jumps in stock prices overwhelmingly arrive around market openings. On average, $49.4 \%$ of the jumps arrive in the first 15 -min intervals after the market opens. This finding is similar to that in Lee and Mykland (20)08), which finds $73 \%$ of the jumps arrive in the first 15 -min interval after the market opens. There is a rising trend for jumps to arrive during the first 15-min interval from $32.1 \%$ in 2003 to $67.9 \%$ in 2008. Panel B of Table 2 shows no clear evidence of seasonality in jump frequency across months. The only exception is April, which accounts for the highest portion of jump arrivals from the year 2003 to 2006. The clustering of jumps in April is likely due to the statutory requirement for all Chinese firms to file their annual reports by April 30 (Haw et al. 2006) ${ }^{6}$ When the market peaked in October 2007, we also observe the largest number of monthly jump arrivals of all months in the sample.

\subsection{Portfolio performance}

Table 3 reports the summary statistics for monthly returns of the decile and quintile portfolios, as well as two long-short portfolios, formed on the jump intensity, which is defined as the monthly sum of absolute daily jump returns over the previous month. Panel A shows that none of the decile portfolios yield significant returns. All decile portfolios are left skewed and fat tailed. However, the long-short decile portfolio, $Q_{1}-Q_{10}$, generates a significantly positive average monthly return of $2.1 \%$ (an annualized return of $28.3 \%$ ) with a monthly Sharp ratio of 0.464 ( 1.67 if annualized). The quintile portfolios exhibit very similar pattern in Panel B. The long-short quintile portfolio, $Q_{1}-Q_{5}$, generates a monthly return of $1.3 \%$ (an annualized return of $16.8 \%$ ). We also examine the profitability of a trading strategy that holds the zerojump portfolio and shorts the highest decile (quintile) portfolio. The zero-jump portfolio includes all stocks that experience no jumps in a given month and is re-balanced every month. On average, the long-short strategies, $Q_{0}-Q_{10}$ and $Q_{0}-Q_{10}$, generate an annualized return of $26.82 \%$ and $16.82 \%$, respectively. The findings are qualitatively similar to those in Yan (20)(8) for the US market whose trading strategy is similar to ours.

We plot the monthly portfolio averages of jump intensities for two decile portfolios in panel (a) of Fig. 1. It is evident that the portfolio averages of jump intensities for the $Q_{10}$ portfolio is always significantly higher than those for the $Q_{1}$ portfolio over the sample period. Panel (b) plots monthly returns of the highest $\left(Q_{10}\right)$ and the lowest $\left(Q_{1}\right)$ decile portfolios. The returns of two decile portfolios move mostly together but the returns of the lowest decile,

${ }^{6} \mathrm{We}$ thanks the referee for suggesting this point. 
Table 3 Descriptive statistics of portlolios returns formed on jump intensity

\begin{tabular}{|c|c|c|c|c|c|c|c|c|c|c|c|}
\hline \multicolumn{12}{|c|}{ Panel A: decile portfolios } \\
\hline Port. & Mean & $t$-statistic & $p$-value & $\beta$ & Std. & Sharpe & Skew. & Kurt. & Min. & Max. & Autocorr. \\
\hline Market & 0.021 & 1.562 & 0.123 & & 0.106 & 0.197 & 0.763 & 3.73 & -0.201 & 0.348 & 0.204 \\
\hline$Q_{0}$ & 0.019 & 1.379 & 0.173 & 0.946 & 0.107 & 0.174 & 0.632 & 4.208 & -0.245 & 0.366 & 0.234 \\
\hline$Q_{1}$ & 0.02 & 1.571 & 0.121 & 0.891 & 0.101 & 0.198 & 0.64 & 3.769 & -0.213 & 0.308 & 0.339 \\
\hline$Q_{2}$ & 0.017 & 1.221 & 0.227 & 0.957 & 0.108 & 0.154 & 0.445 & 3.949 & -0.253 & 0.352 & 0.187 \\
\hline$Q_{3}$ & 0.022 & 1.462 & 0.149 & 1.069 & 0.119 & 0.184 & 0.471 & 4.087 & -0.244 & 0.406 & 0.201 \\
\hline$Q_{4}$ & 0.011 & 0.795 & 0.429 & 0.979 & 0.11 & 0.1 & 0.486 & 3.976 & -0.251 & 0.358 & 0.154 \\
\hline$Q_{5}$ & 0.017 & 1.146 & 0.256 & 1.026 & 0.115 & 0.144 & 0.606 & 3.251 & -0.246 & 0.328 & 0.224 \\
\hline$Q_{6}$ & 0.021 & 1.459 & 0.149 & 1.032 & 0.116 & 0.184 & 0.343 & 3.446 & -0.254 & 0.347 & 0.166 \\
\hline$Q_{7}$ & 0.017 & 1.172 & 0.246 & 1.055 & 0.117 & 0.148 & 0.618 & 3.881 & -0.241 & 0.364 & 0.154 \\
\hline$Q_{8}$ & 0.015 & 1.081 & 0.284 & 1.013 & 0.114 & 0.136 & 0.691 & 3.817 & -0.251 & 0.341 & 0.212 \\
\hline$\widetilde{Q}_{9}$ & 0.012 & 0.851 & 0.398 & 1.037 & 0.116 & 0.107 & 0.467 & 3.5 & -0.249 & 0.336 & 0.126 \\
\hline$Q_{10}$ & -0.001 & -0.073 & 0.942 & 1.059 & 0.121 & -0.009 & 0.313 & 3.081 & -0.278 & 0.297 & 0.083 \\
\hline$Q_{1}-Q_{10}$ & 0.021 & 3.683 & 0.000 & -0.168 & 0.046 & 0.464 & 0.474 & 3.944 & -0.085 & 0.173 & -0.346 \\
\hline$Q_{0}-\widetilde{Q}_{10}$ & 0.02 & 3.843 & 0.000 & -0.112 & 0.041 & 0.484 & 0.543 & 4.231 & -0.079 & 0.161 & -0.337 \\
\hline \multicolumn{12}{|c|}{ Panel B: quintile portfolios } \\
\hline Port. & Mean & $t$-statistic & $p$-value & $\beta$ & Std. & S. R. & Skew. & Kurt. & Min. & Max. & Autocorr. \\
\hline$\overline{Q_{0}}$ & 0.019 & 1.379 & 0.173 & 0.946 & 0.107 & 0.174 & 0.632 & 4.208 & -0.245 & 0.366 & 0.234 \\
\hline$Q_{1}$ & 0.018 & 1.401 & 0.166 & 0.924 & 0.104 & 0.177 & 0.547 & 3.875 & -0.233 & 0.33 & 0.264 \\
\hline$Q_{2}$ & 0.017 & 1.152 & 0.254 & 1.024 & 0.114 & 0.145 & 0.468 & 4.008 & -0.248 & 0.382 & 0.181 \\
\hline$Q_{3}$ & 0.019 & 1.311 & 0.195 & 1.029 & 0.115 & 0.165 & 0.488 & 3.337 & -0.25 & 0.338 & 0.198 \\
\hline$Q_{4}$ & 0.016 & 1.133 & 0.262 & 1.034 & 0.115 & 0.143 & 0.668 & 3.858 & -0.246 & 0.353 & 0.183 \\
\hline$Q_{5}$ & 0.006 & 0.382 & 0.704 & 1.048 & 0.118 & 0.048 & 0.401 & 3.311 & -0.263 & 0.316 & 0.107 \\
\hline$Q_{1}-Q_{5}$ & 0.013 & 3.126 & 0.003 & -0.124 & 0.032 & 0.394 & 0.605 & 4.131 & -0.061 & 0.124 & -0.36 \\
\hline$\widetilde{Q}_{0}-\widetilde{Q}_{5}$ & 0.013 & 3.058 & 0.003 & -0.101 & 0.033 & 0.385 & 0.877 & 6.752 & -0.07 & 0.154 & -0.264 \\
\hline
\end{tabular}

This table reports the description statistics of monthly portfolios returns, together with two long-short portfolios, formed on the jump intensity of the previous month during January 2003 to September 2008. Jimp intensity is defined as the monthly sum of absolute daily jump returns over the formation month. Portfolio $\beta$ is estimated from a market model by regressing the portfolio excess returns on the excess returns of the equally-weighted market index. In Panel $\mathrm{A}$, we form decile portfolios plus a zero-jump portfolio $\left(Q_{0}\right)$ that includes stocks having no jumps during the formation period. The last two rows report the statistics of the long-short zero-cost portfolios by longing the $Q_{1}$ (or zero-jump $Q_{0}$ ) portfolio and shorting the highest decile portfolio. In Panel $\mathrm{B}$, we repeat the exercise for quintile portfolios and the zero-jump portfolio 


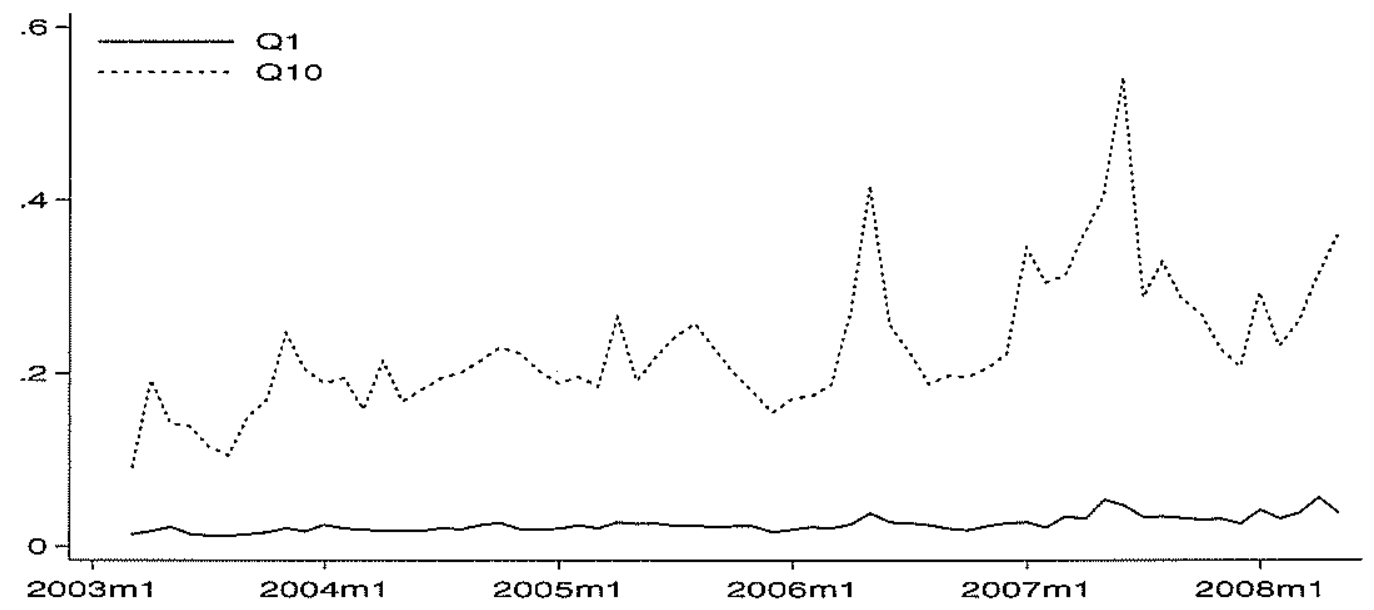

(a) A verage "jump intensity", $\left|r_{j}\right|$, of top and bottom decile portfolios



(b) Monthly returns of top and bottom decile portfolios



(c) Monthly returns of long-short portfolio $Q_{1}-Q_{10}$

Fig. 1 Average "jump intensity", $\left|r_{j}\right|$, and monthly returns of decile portfolios. a Average "jump intensity", $\left|r_{j}\right|$, of top and bottom decile portfolios. b Monthly returns of top and bottom decile portfolios. c Monthly returns of long-short portfolio $Q_{1}-Q_{10}$ 
$Q_{1}$, are higher than the highest decile, $Q_{10}$, in $2 / 3$ of the trading month. Panel (c) plots the monthly returns of long-short portfolio $\left(Q_{1}-Q_{10}\right)$, where the highest (lowest) monthly return is $17.3 \%(-8.5 \%)$. Panel (c) also shows that, during the sample period, the long-short portfolio experienced no more than two consecutive months of losses and suffered the largest cumulative losses of no more than $8.5 \%$.

\subsection{Portfolio performance after controlling for other explanatory variables}

It is possible that jump intensity is related to other risk factors, and therefore, the significant long-short portfolio returns found in Table 3 reflect riskpremium due to risk factors other than the jump risk. To isolate the impact of jump risk on asset pricing, we first sort stocks into five portfolios based on other explanatory variables. Then, within each portfolio we rank stocks by their jump intensities and group them into five sub-portfolios, plus a zero-jump sub-portfolio. In total we obtain thirty portfolios. If other risk variables explain significant long-short portfolio returns we find in Table 3, we would find no significant return between low and high jump intensity portfolios within each quintile portfolio sorted on other risk variables. We reexamine the results in Table 3 after controlling for some common risk variables, including market risk $(\beta)$, past returns $\left(r_{t-1}\right)$, past idiosyncratic returns $\left(r_{i d i o}\right)$, market capitalization (ME), market-to-book ratio (MB), lagged volatility $\left(\sigma\left(r_{t-1}\right)\right)$, stock turnover (TO), and illiquidity (Illiq.) and report the results in Table $4 .{ }^{7}$

The column number 1 through 5 denotes five quintile portfolios sorted on respective risk variables. In most cases the monthly average returns of the longshort portfolios $Q_{0}^{J}-Q_{5}^{J}$ and $Q_{1}^{J}-Q_{5}^{J}$ are always positive and statistically significant within each other-risk-variable-sorted portfolio. The results suggest that the significantly positive excess returns generated from a zero-cost longshort trading strategy based on jump intensity can not be explained by commonly used risk variables, including past returns, past idiosyncratic returns, market capitalization, market-to-book ratio, lagged volatility, stock turnover, and illiquidity.

\subsection{Fama-French three factors and twenty-five Fama-French portfolios}

We next examine whether the positive long-short portfolio returns can be explained by asset pricing models, specifically by the Fama-French three-factor model. As shown in Table 5 , the estimated coefficients on $r_{M}-r_{f}$ for all 11 portfolios are significant, and the loadings on SMB and HML are not significantly different from zero. All of the intercepts from time-series regressions

\footnotetext{
${ }^{7}$ To save space, we only report the zero-jump, first and fifth quintile portfolios sorted on jump intensity within each portfolio sorted on other risk variables. The full table is available upon request.
} 
Table 4 Summary statistics of portfolios returns formed on jump intensity and control variables

\begin{tabular}{|c|c|c|c|c|c|c|c|c|c|c|}
\hline & \multicolumn{5}{|l|}{$\beta$} & \multicolumn{5}{|l|}{$r_{t-1}$} \\
\hline & 1 & 2 & 3 & 4 & 5 & 1 & 2 & 3 & 4 & 5 \\
\hline All & $\begin{array}{l}0.016 \\
(1.237)\end{array}$ & $\begin{array}{l}0.018 \\
(1.304)\end{array}$ & $\begin{array}{l}0.018 \\
(1.251)\end{array}$ & $\begin{array}{l}0.017 \\
(1.121)\end{array}$ & $\begin{array}{l}0.014 \\
(0.949)\end{array}$ & $\begin{array}{l}0.022 \\
(1.478)\end{array}$ & $\begin{array}{l}0.021 \\
(1.439)\end{array}$ & $\begin{array}{l}0.017 \\
(1.193)\end{array}$ & $\begin{array}{l}0.013 \\
(0.973)\end{array}$ & $\begin{array}{c}0.009 \\
(0.633)\end{array}$ \\
\hline$Q_{0}^{J}$ & $\begin{array}{l}0.018 \\
(1.495)\end{array}$ & $\begin{array}{l}0.021 \\
\quad(1.628)\end{array}$ & $\begin{array}{l}0.021 \\
(1.435)\end{array}$ & $\begin{array}{l}0.020 \\
(1.325)\end{array}$ & $\begin{array}{l}0.015 \\
(1.031)\end{array}$ & $\begin{array}{l}0.024 \\
(1.648)\end{array}$ & $\begin{array}{l}0.032 \\
(2.131)\end{array}$ & $\begin{array}{l}0.017 \\
(1.201)\end{array}$ & $\begin{array}{l}0.019 \\
(1.374)\end{array}$ & $\begin{array}{l}0.014 \\
(1.057)\end{array}$ \\
\hline$Q_{1}^{J}$ & $\begin{array}{l}0.017 \\
(1.338)\end{array}$ & $\begin{array}{l}0.016 \\
(1.231)\end{array}$ & $\begin{array}{l}0.023 \\
\quad(1.641)\end{array}$ & $\begin{array}{l}0.022 \\
(1.624)\end{array}$ & $\begin{array}{l}0.016 \\
(1.117)\end{array}$ & $\begin{array}{l}0.026 \\
(1.852)\end{array}$ & $\begin{array}{l}0.022 \\
(1.606)\end{array}$ & $\begin{array}{l}0.021 \\
\quad(1.509)\end{array}$ & $\begin{array}{l}0.020 \\
(1.456)\end{array}$ & $\begin{array}{l}0.017 \\
(1.258)\end{array}$ \\
\hline$Q_{5}^{J}$ & $\begin{array}{l}0.003 \\
(0.200)\end{array}$ & $\begin{array}{l}0.005 \\
(0.364)\end{array}$ & $\begin{array}{l}0.007 \\
(0.486)\end{array}$ & $\begin{array}{l}0.002 \\
(0.124)\end{array}$ & $\begin{array}{l}0.005 \\
(0.342)\end{array}$ & $\begin{array}{l}0.014 \\
(0.864)\end{array}$ & $\begin{array}{l}0.010 \\
\quad(0.681)\end{array}$ & $\begin{array}{l}0.008 \\
(0.563)\end{array}$ & $\begin{array}{l}0.001 \\
(0.054)\end{array}$ & $\begin{array}{l}-0.010 \\
\quad(-0.661)\end{array}$ \\
\hline$Q_{1}^{J}-Q_{5}^{J}$ & $\begin{array}{l}0.014 \\
(2.227)\end{array}$ & $\begin{array}{l}0.01 \\
(1.733)\end{array}$ & $\begin{array}{l}0.016 \\
(2.896)\end{array}$ & $\begin{array}{l}0.02 \\
(4.403)\end{array}$ & $\begin{array}{l}0.011 \\
(2.209)\end{array}$ & $\begin{array}{l}0.012 \\
(1.814)\end{array}$ & $\begin{array}{l}0.011 \\
(2.091)\end{array}$ & $\begin{array}{l}0.012 \\
(2.511)\end{array}$ & $\begin{array}{l}0.02 \\
(3.442)\end{array}$ & $\begin{array}{l}0.027 \\
(3.968)\end{array}$ \\
\hline \multirow[t]{3}{*}{$Q_{0}^{J}-Q_{5}^{J}$} & $\begin{array}{l}0.015 \\
(2.410)\end{array}$ & $\begin{array}{l}0.015 \\
(2.678)\end{array}$ & $\begin{array}{l}0.013 \\
\quad(2.829)\end{array}$ & $\begin{array}{l}0.018 \\
(2.718)\end{array}$ & $\begin{array}{l}0.01 \\
(1.686)\end{array}$ & $\begin{array}{l}0.007 \\
(1.134)\end{array}$ & $\begin{array}{l}0.022 \\
(3.249)\end{array}$ & $\begin{array}{l}0.008 \\
(1.589) \\
\end{array}$ & $\begin{array}{l}0.018 \\
(3.444) \\
\end{array}$ & $\begin{array}{l}0.024 \\
(3.549) \\
\end{array}$ \\
\hline & \multicolumn{5}{|l|}{$r_{t-1}^{\text {idio }}$} & \multicolumn{5}{|c|}{ Market cap.(ME) } \\
\hline & 1 & 2 & 3 & 4 & 5 & 1 & 2 & 3 & 4 & 5 \\
\hline All & $\begin{array}{c}0.021 \\
(1.39)\end{array}$ & $\begin{array}{l}0.021 \\
(1.487)\end{array}$ & $\begin{array}{l}0.017 \\
\quad(1.168)\end{array}$ & $\begin{array}{l}0.014 \\
\quad(1.037)\end{array}$ & $\begin{array}{l}0.009 \\
(0.645)\end{array}$ & $\begin{array}{l}0.016 \\
(0.948)\end{array}$ & $\begin{array}{l}0.016 \\
(1.06)\end{array}$ & $\begin{array}{l}0.016 \\
(1.131)\end{array}$ & $\begin{array}{l}0.016 \\
(1.171)\end{array}$ & $\begin{array}{l}0.019 \\
\quad(1.498)\end{array}$ \\
\hline$Q_{0}^{J}$ & $\begin{array}{l}0.023 \\
(1.554)\end{array}$ & $\begin{array}{l}0.032 \\
\quad(2.095)\end{array}$ & $\begin{array}{l}0.017 \\
(1.267)\end{array}$ & $\begin{array}{l}0.021 \\
\quad(1.464)\end{array}$ & $\begin{array}{l}0.014 \\
(1.085)\end{array}$ & $\begin{array}{l}0.018 \\
(0.987)\end{array}$ & $\begin{array}{l}0.016 \\
(1.088)\end{array}$ & $\begin{array}{l}0.014 \\
(0.949)\end{array}$ & $\begin{array}{l}0.019 \\
\quad(1.427)\end{array}$ & $\begin{array}{l}0.022 \\
\quad(1.773)\end{array}$ \\
\hline$Q_{1}^{J}$ & $\begin{array}{l}0.025 \\
(1.725)\end{array}$ & $\begin{array}{l}0.022 \\
(1.59)\end{array}$ & $\begin{array}{l}0.019 \\
\quad(1.432)\end{array}$ & $\begin{array}{l}0.021 \\
\quad(1.505)\end{array}$ & $\begin{array}{l}0.017 \\
(1.23)\end{array}$ & $\begin{array}{l}0.014 \\
(0.881)\end{array}$ & $\begin{array}{l}0.018 \\
(1.255)\end{array}$ & $\begin{array}{l}0.016 \\
(1.198)\end{array}$ & $\begin{array}{l}0.025 \\
\quad(1.865)\end{array}$ & $\begin{array}{l}0.018 \\
(1.432)\end{array}$ \\
\hline$Q_{5}^{J}$ & $\begin{array}{l}0.011 \\
(0.678)\end{array}$ & $\begin{array}{l}0.013 \\
(0.823)\end{array}$ & $\begin{array}{l}0.006 \\
(0.436)\end{array}$ & $\begin{array}{l}0.002 \\
(0.142)\end{array}$ & $\begin{array}{l}-0.009 \\
\quad(-0.625)\end{array}$ & $\begin{array}{l}0.003 \\
(0.172)\end{array}$ & $\begin{array}{l}0.005 \\
(0.319)\end{array}$ & $\begin{array}{l}0.006 \\
(0.369)\end{array}$ & $\begin{array}{l}0.004 \\
(0.276)\end{array}$ & $\begin{array}{l}0.014 \\
(1.053)\end{array}$ \\
\hline$Q_{1}^{J}-Q_{5}^{I}$ & $\begin{array}{l}0.014 \\
(2.245)\end{array}$ & $\begin{array}{l}0.008 \\
(1.521)\end{array}$ & $\begin{array}{l}0.013 \\
(3.067)\end{array}$ & $\begin{array}{l}0.019 \\
(3.396)\end{array}$ & $\begin{array}{l}0.026 \\
(3.887)\end{array}$ & $\begin{array}{l}0.011 \\
(1.881)\end{array}$ & $\begin{array}{l}0.013 \\
(2.32)\end{array}$ & $\begin{array}{l}0.01 \\
(2.014)\end{array}$ & $\begin{array}{l}0.021 \\
(3.656)\end{array}$ & $\begin{array}{l}0.004 \\
(0.838)\end{array}$ \\
\hline$Q_{0}^{J}-Q_{5}^{J}$ & $\begin{array}{l}0.009 \\
(1.55)\end{array}$ & $\begin{array}{l}0.019 \\
(2.658)\end{array}$ & $\begin{array}{l}0.011 \\
(2.215)\end{array}$ & $\begin{array}{l}0.019 \\
(3.759)\end{array}$ & $\begin{array}{l}0.023 \\
(3.308)\end{array}$ & $\begin{array}{l}0.017 \\
(2.492) \\
\end{array}$ & $\begin{array}{l}0.011 \\
(2.582) \\
\end{array}$ & $\begin{array}{l}0.008 \\
(1.622) \\
\end{array}$ & $\begin{array}{l}0.015 \\
(3.129) \\
\end{array}$ & $\begin{array}{l}0.008 \\
(1.486) \\
\end{array}$ \\
\hline
\end{tabular}


Table 4 (continued)

\begin{tabular}{|c|c|c|c|c|c|c|c|c|c|c|}
\hline & \multicolumn{5}{|c|}{ Market-to-book ratio (MB) } & \multicolumn{5}{|l|}{$\sigma\left(r_{t-1}\right)$} \\
\hline & 1 & 2 & 3 & 4 & 5 & 1 & 2 & 3 & 4 & 5 \\
\hline All & $\begin{array}{l}0.021 \\
(1.403)\end{array}$ & $\begin{array}{l}0.02 \\
(1.382)\end{array}$ & $\begin{array}{l}0.017 \\
(1.213)\end{array}$ & $\begin{array}{l}0.016 \\
(1.154)\end{array}$ & $\begin{array}{l}0.010 \\
(0.743)\end{array}$ & $\begin{array}{l}0.020 \\
(1.574)\end{array}$ & $\begin{array}{l}0.022 \\
(1.635)\end{array}$ & $\begin{array}{l}0.019 \\
(1.285)\end{array}$ & $\begin{array}{l}0.014 \\
(0.966)\end{array}$ & $\begin{array}{l}0.007 \\
(0.456)\end{array}$ \\
\hline$Q_{0}^{I}$ & $\begin{array}{l}0.019 \\
(1.162)\end{array}$ & $\begin{array}{l}0.023 \\
(1.559)\end{array}$ & $\begin{array}{l}0.02 \\
(1.402)\end{array}$ & $\begin{array}{l}0.017 \\
(1.233)\end{array}$ & $\begin{array}{l}0.014 \\
(1.159)\end{array}$ & $\begin{array}{l}0.021 \\
(1.691)\end{array}$ & $\begin{array}{l}0.023 \\
(1.622)\end{array}$ & $\begin{array}{l}0.014 \\
(1.054)\end{array}$ & $\begin{array}{l}0.02 \\
(1.305)\end{array}$ & $\begin{array}{l}0.011 \\
(0.74)\end{array}$ \\
\hline$Q_{1}^{J}$ & $\begin{array}{l}0.024 \\
(1.682)\end{array}$ & $\begin{array}{l}0.021 \\
(1.492)\end{array}$ & $\begin{array}{l}0.017 \\
(1.268)\end{array}$ & $\begin{array}{l}0.017 \\
(1.34)\end{array}$ & $\begin{array}{l}0.018 \\
\quad(1.429)\end{array}$ & $\begin{array}{l}0.018 \\
\quad(1.556)\end{array}$ & $\begin{array}{l}0.025 \\
(1.852)\end{array}$ & $\begin{array}{l}0.023 \\
\quad(1.657)\end{array}$ & $\begin{array}{l}0.016 \\
(1.08)\end{array}$ & $\begin{array}{l}0.012 \\
\quad(0.737)\end{array}$ \\
\hline$Q_{5}^{J}$ & $\begin{array}{l}0.014 \\
(0.849)\end{array}$ & $\begin{array}{l}0.007 \\
(0.476)\end{array}$ & $\begin{array}{l}0.011 \\
(0.78)\end{array}$ & $\begin{array}{l}0.005 \\
(0.379)\end{array}$ & $\begin{array}{l}-0.006 \\
\quad(-0.401)\end{array}$ & $\begin{array}{l}0.021 \\
\quad(1.444)\end{array}$ & $\begin{array}{l}0.021 \\
(1.464)\end{array}$ & $\begin{array}{l}0.018 \\
\quad(1.175)\end{array}$ & $\begin{array}{l}0.009 \\
(0.597)\end{array}$ & $\begin{array}{l}-0.007 \\
\quad(-0.466)\end{array}$ \\
\hline$Q_{1}^{J}-Q_{5}^{J}$ & $\begin{array}{l}0.01 \\
(2.000)\end{array}$ & $\begin{array}{l}0.014 \\
(3.206)\end{array}$ & $\begin{array}{l}0.005 \\
(1.143)\end{array}$ & $\begin{array}{l}0.012 \\
(2.261)\end{array}$ & $\begin{array}{l}0.025 \\
(3.347)\end{array}$ & $\begin{array}{l}-0.002 \\
\quad(-0.398)\end{array}$ & $\begin{array}{l}0.004 \\
(0.637)\end{array}$ & $\begin{array}{l}0.005 \\
(0.953)\end{array}$ & $\begin{array}{l}0.007 \\
(1.56)\end{array}$ & $\begin{array}{l}0.019 \\
\quad(3.219)\end{array}$ \\
\hline \multirow[t]{3}{*}{$Q_{0}^{J}-Q_{5}^{J}$} & $\begin{array}{l}0.005 \\
(0.941)\end{array}$ & $\begin{array}{l}0.016 \\
(3.42)\end{array}$ & $\begin{array}{l}0.008 \\
(1.663)\end{array}$ & $\begin{array}{l}0.011 \\
(2.473)\end{array}$ & $\begin{array}{l}0.020 \\
(2.856)\end{array}$ & $\begin{array}{l}0.000 \\
(0.068)\end{array}$ & $\begin{array}{l}0.002 \\
(0.32)\end{array}$ & $\begin{array}{r}-0.003 \\
\quad(-0.641)\end{array}$ & $\begin{array}{l}0.011 \\
(1.907)\end{array}$ & $\begin{array}{l}0.018 \\
(2.807)\end{array}$ \\
\hline & \multicolumn{5}{|c|}{ Turnover } & \multicolumn{5}{|l|}{ Illiquidity } \\
\hline & 1 & 2 & 3 & 4 & 5 & 1 & 2 & 3 & 4 & 5 \\
\hline All & $\begin{array}{l}0.020 \\
(1.671)\end{array}$ & $\begin{array}{l}0.023 \\
(1.662)\end{array}$ & $\begin{array}{l}0.02 \\
(1.378)\end{array}$ & $\begin{array}{l}0.015 \\
(1.002)\end{array}$ & $\begin{array}{l}0.003 \\
(0.221)\end{array}$ & $\begin{array}{l}0.018 \\
(1.493)\end{array}$ & $\begin{array}{l}0.019 \\
(1.393)\end{array}$ & $\begin{array}{l}0.017 \\
(1.218)\end{array}$ & $\begin{array}{l}0.015 \\
(0.975)\end{array}$ & $\begin{array}{l}0.013 \\
(0.782)\end{array}$ \\
\hline$Q_{0}^{J}$ & $\begin{array}{l}0.022 \\
(1.740)\end{array}$ & $\begin{array}{l}0.025 \\
(1.694)\end{array}$ & $\begin{array}{l}0.019 \\
(1.363)\end{array}$ & $\begin{array}{l}0.012 \\
(0.81)\end{array}$ & $\begin{array}{l}0.003 \\
(0.187)\end{array}$ & $\begin{array}{l}0.020 \\
(1.696)\end{array}$ & $\begin{array}{l}0.021 \\
(1.558)\end{array}$ & $\begin{array}{l}0.016 \\
\quad(1.129)\end{array}$ & $\begin{array}{l}0.015 \\
(0.938)\end{array}$ & $\begin{array}{l}0.017 \\
(0.963)\end{array}$ \\
\hline$Q_{1}^{l}$ & $\begin{array}{l}0.019 \\
(1.620)\end{array}$ & $\begin{array}{l}0.024 \\
(1.795)\end{array}$ & $\begin{array}{l}0.020 \\
(1.424)\end{array}$ & $\begin{array}{l}0.016 \\
(1.052)\end{array}$ & $\begin{array}{l}0.004 \\
\quad(0.285)\end{array}$ & $\begin{array}{l}0.018 \\
(1.486)\end{array}$ & $\begin{array}{l}0.024 \\
(1.776)\end{array}$ & $\begin{array}{l}0.02 \\
(1.483)\end{array}$ & $\begin{array}{l}0.014 \\
(0.956)\end{array}$ & $\begin{array}{l}0.012 \\
\quad(0.740)\end{array}$ \\
\hline$Q_{5}^{J}$ & $\begin{array}{l}0.013 \\
(1.008)\end{array}$ & $\begin{array}{l}0.019 \\
(1.274)\end{array}$ & $\begin{array}{l}0.015 \\
(0.982)\end{array}$ & $\begin{array}{l}0.007 \\
(0.462)\end{array}$ & $\begin{array}{r}-0.011 \\
\quad(-0.697)\end{array}$ & $\begin{array}{l}0.018 \\
\quad(1.344)\end{array}$ & $\begin{array}{l}0.014 \\
(1.036)\end{array}$ & $\begin{array}{l}0.007 \\
(0.446)\end{array}$ & $\begin{array}{l}0.005 \\
(0.348)\end{array}$ & $\begin{array}{l}-0.004 \\
(-0.227)\end{array}$ \\
\hline$Q_{1}^{J}-Q_{5}^{J}$ & $\begin{array}{l}0.006 \\
(1.045)\end{array}$ & $\begin{array}{l}0.005 \\
(1.051)\end{array}$ & $\begin{array}{l}0.005 \\
(0.971)\end{array}$ & $\begin{array}{l}0.009 \\
(1.397)\end{array}$ & $\begin{array}{l}0.015 \\
(2.431)\end{array}$ & $\begin{array}{l}0.001 \\
(0.110)\end{array}$ & $\begin{array}{l}0.010 \\
(1.711)\end{array}$ & $\begin{array}{l}0.013 \\
\quad(2.655)\end{array}$ & $\begin{array}{l}0.009 \\
(1.963)\end{array}$ & $\begin{array}{l}0.016 \\
\quad(3.474)\end{array}$ \\
\hline$Q_{0}^{J}-Q_{5}^{J}$ & $\begin{array}{l}0.008 \\
(1.616)\end{array}$ & $\begin{array}{l}0.006 \\
\quad(1.259)\end{array}$ & $\begin{array}{l}0.005 \\
(0.916)\end{array}$ & $\begin{array}{l}0.005 \\
\quad(0.851)\end{array}$ & $\begin{array}{l}0.014 \\
\quad(2.238)\end{array}$ & $\begin{array}{l}0.003 \\
(0.537)\end{array}$ & $\begin{array}{l}0.006 \\
(1.27)\end{array}$ & $\begin{array}{l}0.009 \\
(2.309)\end{array}$ & $\begin{array}{l}0.010 \\
(2.075) \\
\end{array}$ & $\begin{array}{l}0.023 \\
(3.777)\end{array}$ \\
\hline
\end{tabular}

This table reports the average monthly returns and their $t$-statistics of 30 portfolios formed on jump intensity and various control variables, including market risk


and illiquidity 
Table 5 Results of time-series regressions on Fama-French three factors

\begin{tabular}{|c|c|c|c|c|c|}
\hline Portfolio & Intercept & $r_{M}-r_{f}$ & SMB & HML & $R^{2}$ \\
\hline$Q_{0}$ & $\begin{array}{l}0.447 \\
\quad(3.218)\end{array}$ & $\begin{array}{l}0.887 \\
(4.074)\end{array}$ & $\begin{array}{l}0.048 \\
(0.131)\end{array}$ & $\begin{array}{l}0.006 \\
(0.521)\end{array}$ & 0.307 \\
\hline$Q_{1}$ & $\begin{array}{l}0.394 \\
(2.915)\end{array}$ & $\begin{array}{l}0.862 \\
(4.075)\end{array}$ & $\begin{array}{l}0.238 \\
(0.664)\end{array}$ & $\begin{array}{l}0.007 \\
(0.611)\end{array}$ & 0.282 \\
\hline$Q_{2}$ & $\begin{array}{l}0.376 \\
(2.68)\end{array}$ & $\begin{array}{l}0.997 \\
(4.544)\end{array}$ & $\begin{array}{l}0.214 \\
(0.575)\end{array}$ & $\begin{array}{l}0.005 \\
\quad(0.398)\end{array}$ & 0.31 \\
\hline$Q_{3}$ & $\begin{array}{l}0.476 \\
(3.064)\end{array}$ & $\begin{array}{l}1.093 \\
(4.497)\end{array}$ & $\begin{array}{l}0.223 \\
(0.542)\end{array}$ & $\begin{array}{l}0.007 \\
(0.53)\end{array}$ & 0.321 \\
\hline$Q_{4}$ & $\begin{array}{l}0.454 \\
\quad(3.257)\end{array}$ & $\begin{array}{l}1.016 \\
(4.656)\end{array}$ & $\begin{array}{l}0.09 \\
(0.244)\end{array}$ & $\begin{array}{r}-0.002 \\
(0.154)\end{array}$ & 0.347 \\
\hline$Q_{5}$ & $\begin{array}{l}0.511 \\
\quad(3.606)\end{array}$ & $\begin{array}{l}1.099 \\
(4.959)\end{array}$ & $\begin{array}{l}0.009 \\
(0.025)\end{array}$ & $\begin{array}{l}0.003 \\
(0.214)\end{array}$ & 0.387 \\
\hline$Q_{6}$ & $\begin{array}{l}0.461 \\
(3.2)\end{array}$ & $\begin{array}{l}1.172 \\
(5.197)\end{array}$ & $\begin{array}{l}0.205 \\
(0.537)\end{array}$ & $\begin{array}{l}0.007 \\
(0.568)\end{array}$ & 0.377 \\
\hline$Q_{7}$ & $\begin{array}{l}0.466 \\
(3.133)\end{array}$ & $\begin{array}{l}1.166 \\
(5.004)\end{array}$ & $\begin{array}{l}0.279 \\
\quad(0.707)\end{array}$ & $\begin{array}{l}0.002 \\
\quad(0.165)\end{array}$ & 0.357 \\
\hline$Q_{8}$ & $\begin{array}{l}0.472 \\
(3.381)\end{array}$ & $\begin{array}{l}1.107 \\
(5.062)\end{array}$ & $\begin{array}{r}-0.047 \\
(0.127)\end{array}$ & $\begin{array}{l}0.003 \\
\quad(0.259)\end{array}$ & 0.39 \\
\hline$Q_{9}$ & $\begin{array}{l}0.462 \\
(3.149)\end{array}$ & $\begin{array}{l}1.125 \\
(4.891)\end{array}$ & $\begin{array}{l}0.134 \\
\quad(0.343)\end{array}$ & $\begin{array}{r}-0.001 \\
(0.098)\end{array}$ & 0.357 \\
\hline$Q_{10}$ & $\begin{array}{l}0.566 \\
(4.018)\end{array}$ & $\begin{array}{l}1.235 \\
(5.604)\end{array}$ & $\begin{array}{r}-0.127 \\
(0.339)\end{array}$ & $\begin{array}{r}-0.015 \\
(1.233)\end{array}$ & 0.454 \\
\hline$Q_{1}-Q_{10}$ & $\begin{array}{l}-0.174 \\
\quad(3.053)\end{array}$ & $\begin{array}{r}-0.375 \\
(4.189)\end{array}$ & $\begin{array}{l}0.366 \\
(2.415)\end{array}$ & $\begin{array}{l}0.02 \\
(4.043)\end{array}$ & 0.415 \\
\hline$Q_{0}-Q_{10}$ & $\begin{array}{r}-0.121 \\
\quad(2.176) \\
\end{array}$ & $\begin{array}{r}-0.35 \\
(4.025)\end{array}$ & $\begin{array}{l}0.176 \\
\quad(1.196) \\
\end{array}$ & $\begin{array}{l}0.019 \\
(3.976) \\
\end{array}$ & 0.314 \\
\hline
\end{tabular}

We ran time-series regressions of monthly returns of the $i$ th decile portfolio formed on jump intensity and the long-short portfolios $Q_{1}-Q_{10}$ and $Q_{0}-Q_{10}$ on three Fama-French factors. $r_{i . t}-$ $r_{j, l}=\alpha_{i}+\gamma_{1 . i}\left(r_{M}-r_{j}\right)_{t}+\gamma_{2, i} S M B_{t}+\gamma_{3, i} H M L_{t}+\varepsilon_{t, i}, t$-statistics are shown in the parentheses

are significantly positive. Not surprisingly, the null hypothesis that the intercepts are jointly zero for all 11 portfolios formed on jump intensity are strongly rejected with a $p$-value of $0.000 \%$ by the $F$-test of Gibbons et al. (1989). Moreover, the explanatory powers of the three factors are $28.2 \%$ for the first decile portfolio and $45.4 \%$ for the 10 th decile portfolio.

\subsection{Fama-MacBeth regressions}

Table 6 reports results from the Fama-MacBeth cross-sectional regression model as specified in Eq. 8. In Model I of Table 6, we form 11 test portfolios on jump intensity only. In Model II-VIII, 30 test portfolios are formed first on a control variable, and then on jump intensity. The control variables include past return $\left(r_{t-1}\right)$, past idiosyncratic returns $\left(r_{t-1}^{i d i o}\right)$, market capitalization (ME), Market-to-book ratio (MB), lagged volatility $\left(\sigma_{r_{t-1}}\right)$, stock turnover (TO), and illiquidity (Illiq.)

For each month, equally-weighted portfolio excess returns are regressed on stock characteristics following the Fama and MacBeth (197.3) method as specified in Eq. 8. Cross-sectional regressions are repeated every month for 
Table 6 Results from Fama-MacBeth regressions

\begin{tabular}{|c|c|c|c|c|c|c|c|c|}
\hline & I & II & III & IV & $\mathrm{V}$ & VI & VII & VIII \\
\hline$r^{j t(m) p}$ & $\begin{array}{r}-0.124 \\
(-5.541)\end{array}$ & $\begin{array}{l}-0.108 \\
(-4.471)\end{array}$ & $\begin{array}{l}-0.114 \\
(-4.592)\end{array}$ & $\begin{array}{l}-0.083 \\
(-5.025)\end{array}$ & $\begin{array}{l}-0.092 \\
(-4.727)\end{array}$ & $\begin{array}{l}-0.05 \\
(-2.248)\end{array}$ & $\begin{array}{r}-0.056 \\
(-2.55)\end{array}$ & $\begin{array}{r}-0.068 \\
(-4.797)\end{array}$ \\
\hline$\beta^{p o n t}$ & $\begin{array}{l}0.038 \\
(1.615)\end{array}$ & $\begin{array}{l}0.006 \\
(0.289)\end{array}$ & $\begin{array}{l}0.017 \\
(0.858)\end{array}$ & $\begin{array}{l}0.005 \\
(0.206)\end{array}$ & $\begin{array}{l}0.021 \\
(1.005)\end{array}$ & $\begin{array}{l}0.026 \\
(1.533)\end{array}$ & $\begin{array}{l}0.029 \\
(1.473)\end{array}$ & $\begin{array}{l}0.005 \\
(0.216)\end{array}$ \\
\hline$r_{t-1}$ & & $\begin{array}{l}-0.039 \\
\quad(-1.409)\end{array}$ & & & & & & \\
\hline ritio & & & $\begin{array}{l}-0.027 \\
\quad(-0.982)\end{array}$ & & & & & \\
\hline Market Cap. & & & & $\begin{array}{l}0.000 \\
(1.103)\end{array}$ & & & & \\
\hline $\mathrm{MB}$ & & & & & $\begin{array}{l}-0.001 \\
\quad(-2.193)\end{array}$ & & & \\
\hline$\sigma_{r_{t-1}}$ & & & & & & $\begin{array}{l}-0.761 \\
\quad(-2.785)\end{array}$ & & \\
\hline Turnover & & & & & & & $\begin{array}{l}-0.032 \\
\quad(-4.867)\end{array}$ & \\
\hline Illiquidity & & & & & & & & $\begin{array}{l}-0.106 \\
(-1.099)\end{array}$ \\
\hline
\end{tabular}

This table reports the results of Fama-MacBeth cross section regressions of monthly portfolio returns in each month. Model I estimates the cross-section regression using 11 portlolios $\left(Q_{0}, Q_{1}, Q_{2}, \cdots, Q_{i}, \cdots Q_{10}\right)$ sorted on jump intensity for each month:

$$
r_{i}-r_{j}=\alpha+\gamma_{1} r_{i}^{j u m p}+\gamma_{2} \beta_{i}^{\text {porr. }}+\varepsilon_{i} .
$$

Model II-VIII estimate the cross section regression using 30 double-sorted portfolios $(i=1,2, \cdots, 30)$ for each month, while controlling for the effect of portfolio market $\beta$ :

$$
r_{i}-r_{j}=\alpha+\gamma_{1} r_{i}^{j ! m p}+\gamma_{2} \beta_{i}^{p o r t}+\gamma_{3} \operatorname{Sor} V a_{i}+\varepsilon_{i},
$$

where Sort Var is the monthly portiolio average of past return $\left(r_{t-1}\right)$, past idiosyncratic returns ( $\left.r_{t-1}^{\text {idio }}\right)$, market capitalization (ME), market-to-book ratio (MB), lagged volatility $\left(\sigma_{r_{t-1}}\right)$, stock turnover (TO), or illiquidity (Illiq.) across all stocks in the $i$ th portfolio. $t$-statistics are shown in the parentheses 
63 months. Time series averages of estimated regression coefficients $\gamma$ 's are computed for jump intensity, market risk, and the stock characteristic variable, and are tested for significance via a $t$-test for a mean of zero.

In Model I, the coefficient for $r_{i}^{\text {jump }}$, denoted as $\gamma_{1}$, has a statistically significant mean of $-0.124(t=-5.541)$, and its median is -0.102 . The results strongly support that jump intensity is priced, consistent with the hypothesis that excess stock returns are monotonically decreasing in jump intensity. The serial correlation of the series $\gamma_{1}$ is at a negligible level of -0.113 . The positive coefficient of market risk, $\beta$, is consistent with CAPM.

Estimation results of the cross-sectional model specified in Eq. 8 controlling for additional risk factors are presented in the rest of the columns in Table 6 (Model II-VIII). The coefficients for $r_{i}^{j t m p}$ remain negative and are significant at conventional significance levels, regardless of the control risk factors included in the regression.

As expected, the coefficient of market risk, $\beta$, is positive and significant. However, it becomes insignificant when lagged returns, past idiosyncratic returns, size, market-to-book ratio, or illiquidity are included as control variables. The significantly negative coefficient of lagged returns are consistent with findings that contrarian strategies are profitable over short-horizon in China's stock market. In addition, the coefficients of market-to-book ratio, lagged volatility, and turnover are significantly negative.

The above results overwhelmingly support the hypothesis that jump risk measured by jump intensity is systematic and is cross-sectionally priced in the market. The results are robust to controlling for other risk factors.

\section{Conclusion}

In this paper we present strong empirical evidence suggesting that crosssectional expected stock returns are related to the variation in jump risks measured by jump intensity. Using a stylized diffusion-jump model that allows for the dependence of jump dynamics in the SDF and the stock price, we test the hypothesis on the mechanism of how the jump intensities across stocks systematically explain the cross-sectional variation in expected excess returns.

To empirically test the hypothesis, we rely on the non-parametric jumpdetection method developed by Lee and Mykland to pinpoint the intraday intervals over which price jumps arrive, and to jointly estimate the jump frequency and daily jump returns. Using high frequency trading data from China's stock market we find that jumps are rare events, on average occurring on $6.8 \%$ of the trading days, consistent with previous empirical findings with the U.S. data. We also document that about half of the jumps arrive during the first 15 min after market opening, while jump arrival show no obvious patterns over different months of the years.

We then form decile and quintile portfolios based on jump intensity, defined as the monthly sum of absolute daily jump returns. On average, a trading 
strategy that longs the lowest decile (quintile) portfolio and shorts the highest decile (quintile) portfolio yields an annualized profit of $28 \%$. A trading strategy of longing the zero-jump portfolio, a monthly rebalanced portfolio includes all stock experienced no jump in a given month, and shorting the highest decile (quintile) portfolio on average generates profits of similar magnitude over the sample period. Next we examine the possibility that the excess jump returns are caused by other risk factors, including market risk, lag return, lag idiosyncratic returns, market capitalization, market-to-book ratio, lagged volatility, stock turnover, and illiquidity. We form 30 double sorted portfolios using one of the risk factors and the jump risk to reexamine the significance of returns on the long-short strategy. Evidence shows that, after controlling for various risk factors, excess returns borne from the trading strategy that longs the lowest jump quintile portfolio and shorts the highest jump quintile portfolio continue to be significantly positive. The above findings are confirmed by a Fama-MacBeth analysis. After controlling for various risk variables, the jump variable is still an important factor that determines the excess returns on 11 single-sort portfolios. Analysis based on the Fama-Frech three factor model shows that the excess returns on the long-short strategy cannot be explained by market excess return, size, or value factors.

\section{References}

Aït-Sahalia Y (2004) Disentangling diffusion from jumps. J Financ Econ 74:487-528

Amihud Y (2002) Illiquidity and stock returns: cross-section and time-series effects. J Financ Mark $5: 31-56$

Andersen TG, Benzoni L, Lund J (2002) An empirical investigation of continuous-time equity return models. J Finance 57:1239-1284

Bakshi G, Cao C, Chen Z (1997) Empirical performance of alternative option pricing models. J Finance 52:589-667

Ball CA, Torous WN (1985) On jumps in common stock prices and their impact on call option pricing. J Finance 40:155-173

Barndorff-Nielsen OE, Shephard N (2006) Econometrics of testing for jumps in financial economics using bipower variation. J Financ Econ 4:1-30

Barro RJ (2006) Rare disasters and asset markets in the twentieth century. Q J Econ 121:823-866

Bates D (2000) Post-'87 crash fears in the S\&P 500 futures option market. J Econom 94:181-238

Bollerslev T, Law TH, George T (2008) Risk, jumps, and diversification. J Econom 144:234-256

Breeden DT (1979) An intertemporal asset pricing model with stochastic consumption and investment opportunities. J Financ Econ 7:265-296

Cochrane JH (2005) Asset pricing. Princeton Unversity Press, Princeton

Cox JC, Ross SA (1976) The valuation of options for alternative stochastic processes. J Financ Econ 3:145-166

Duffie D, Pan J, Singleton K (2000) Transform analysis and asset pricing for affine jump-diff usions. Econometrica 68:1343-1376

Dunham LM, Friesen GC (2007) An empirical examination of jump risk in U.S. equity and bond markets. N Am Actuar J 11:76-91

Eraker B (2004) Do stock prices and volatility jump? Reconciling evidence from spot and option prices. J Finance 59:1367-1404

Eraker B, Johannes M, Polson N (2003) The impact of jumps in volatility and returns. J Finance 58:1269-1300

Fama EF, French KR (1993) Common risk factors in the returns on stocks and bonds. J Financ Econ $33: 3-53$ 
Fama EF, MacBeth JD (1973) Risk, return, and equilibrium: empirical tests. J Polit Econ 81:607636

Gibbons MR, Ross SA, Shanken J (1989) A test of the efficiency of a given portfolio. Econometrica 57:1121-1152

Haw I-M, Park KJ, Qi D, Wu W (2006) Securities regulation, the timing of annual report release, and market implications: evidence from China. J Int Financ Manag Account 17:110-139

Jiang GJ, Oomen RCA (2008) Testing for jumps when asset prices are observed with noise-a "swap variance" approach. J Econom 144:352-370

Johnnes M (2004) The statistical and economic role of jumps in continuous-time interest rate models. J Finance 59:227-260

Lee SS, Mykland PA (2008) Jumps in financial markets: a new nonparametric test and jump dynamics. Rev Financ Stud 21:2535-2563

Maheu JM, McCurdy TH (2004) News arrival, jump dynamics, and volatility components for individual stock returns. J Finance 59:755-793

Merton RC (1976) Option pricing when the underlying stock returns are discountinous. J Financ Econ 4:125-144

Naik V, Lee M (1990) General equilibrium pricing of options on the market portfolio with discontinuous returns. Rev Financ Stud 3:493-521

Pan $\mathbf{J}$ (2002) The jump-risk premia implicit in options: evidence from an integrated time-series study. J Financ Econ 63:3-50

Press JS (1967) A compound events model for security prices. J Bus 40:317-335

Rietz TA (1988) The equity risk premium a solution. J Monet Econ 22:117-131

Yan S (2008) Jump risk, stock returns, and slope of implied volatility smile. Working paper, University of South Carolina

Zhou H, Zhu Q (2009a) Asset pricing, jump risk, and China's b-share discount puzzle, Working paper Clevealand State University and Shanghai Jiao Tong University

Zhou H, Zhu Q (2009b) An empirical examination of jump risk in asset pricing and volatility forecasting in China's equity and bond markets. Pac Basin Finance J. doi:1(1.1016/ j.pactin.20040.05. 0105 